factor activities in both the fetal lamb and in the mother ewe. The changes were not consistent with classical disseminated intravascular coagulation. An additional stress such as hypotension is probably required to induce intravascular coagulation in the fetus. The exact mechanism responsible for the observed changes remains unclear. The changes are not related to mere exposure of fetal blood to a lowered $\mathrm{pH}$. The observation that the mother ewes also experience a reduction in factor $\mathrm{V}$ and factor IX activity in the absence of lactic acidosis suggests the liberation of a mediator from the fetus capable of crossing the placenta. These observations support the original findings of Bishop et al. (3) which also suggested the liberation of a factor or factors capable of crossing the placenta and influencing coagulation activity in both fetal and maternal blood.

\section{REFERENCES}

1. Ainsworth L, Hackett A, Heaney D, Longford G, Peters H 1977 Management of Reproduction in Sheep and Goats. A multi-disciplinary approach to the development of controlled breeding and intensive production systems for sheep. University of Wisconsin Press, Madison, WI, July 24

2. Biland L, Duckert F 1973 Coagulation factors of the newborn and his mother. Thromb Diath Haemorrh 29:644

3. Bishop AJ, Israelis LG, Chernick V, Israels ED 1971 Placental transfer of intravascular coagulation between mother and child. Pediatr Res 5:113

4. Broersma RJ, Bullemer GD, Mammen EF 1969. Blood coagulation changes in hemorrhagic shock and acidosis. Thromb Diath Haemorrh 36(suppl):171

5. Cade JF, Hirsh J, Martin M 1969 Placental barrier to coagulation factors: Its relevance to the coagulation defect at birth and to haemorrhage in the newborn. Br Med J 2:281
6. Crowell JW, Houston B 1961 Effect of acidity on blood coagulation. Am J Physiol 201:379

7. Hardaway RM, Elovitz MJ, Brewster WR, Houchen DN 1964 Clotting time of heparinized blood-influence of acidosis. Arch Surg 89:701

8. Kisker CT 1979 Detection of fibrin monomer. J Clin Pathol 72:405

9. Kisker CT, Robillard JE, Clarke WR 1981 Development of blood coagulation-a fetal lamb model. Pediatr Res 15:1045

10. Kisker CT, Robillard JE, Clarke WR 1982 Blood coagulation changes after hypoxemia: a fetal lamb model. Pediatr Res 16:8

11. Kisker CT, Robillard JE, Clarke WR 1982 Blood coagulation changes following hypoxemia in the near term fetal lamb. Pediatr Res 16:732

12. Merskey C, Lalezari P, Johnson A A rapid simple sensitive method for measuring fibrinolytic slip products in human serum. Proc Soc Exp Biol Med 131:871

13. Nagasue N, Iwaki A, Yakaya H, Koyanagi N, Kobayashi M, Inokuchi K 1977 Disseminated intravascular coagulation and refractory shock induced by splanchnic metabolic acidosis. Surg Gynecol Obstet 144:519

14. Nossel HL, Lanzkowsky P, Levy S, Mibashan RS, Hansen JD 1966 A study of coagulation factor levels in women during labor and in their newborn infants. Thromb Diath Haemorrh 16:185

15. Owen CA, Bowie E, Didisheim P 1966 Test of hemostasis and blood coagulation. In: Cawley LP (ed) The Diagnosis of Bleeding Disorders. Little, Brown \& Co., Boston, pp 101-107

16. Proctor RR, Rapaport S 1961 The partial thromboplastin time with kaolin: simple screening test for first stage plasma clotting factor deficiencies. Am J Clin Pathol 36:212

17. Rivers RPA, Hathaway WE 1975 Studies on tissue factor activity and production by leukocytes of human umbilical cord and adult origin. Pediatr Res 9:167

18. Robillard JE, Matson J, Sessions C, Smith F: Developmental aspects of renal tubular reabsorption of water in the lamb fetus. Pediatr Res 13:1172

19. Cartwright GE 1968 Prothrombin time. In: Cartwright GE (ed) Diagnostic Laboratory Hematology. Grune and Stratton, Inc, New York, pp 373-377

\title{
Pituitary-Gonadal Function in Klinefelter Syndrome before and during Puberty
}

\author{
JAMES A. SALBENBLATT, BRUCE G. BENDER, MARY H. PUCK, ARTHUR ROBINSON, \\ CHARLES FAIMAN, AND JEREMY S. D. WINTER \\ National Jewish Hospital and Research Center/National Asthma Center; Departments of Pediatrics, Psychiatry, \\ and Biochemistry, Biophysics and Genetics, University of Colorado School of Medicine, Denver, Colorado \\ [J.A.S., B.G.B., M.H.P., A.R.]; and the Departments of Paediatrics, Medicine and Physiology, University of \\ Manitoba, Winnipeg, Manitoba, Canada [C.F., J.S.D.W.]
}

\begin{abstract}
Serum concentrations of follicle-stimulating hormone, luteinizing hormone, testosterone, and estradiol were determined at intervals before and during puberty in 40 individuals with Klinefelter syndrome $(47, X X Y$ karyotype), of whom 27 had been detected in neonatal cytogenetic screening programs. Prior to the appearance of sec-
\end{abstract}

Received March 12, 1984; accepted July 27, 1984

Address for correspondence Arthur Robinson, M.D., National Jewish Hospital and Research Center, 3800 East Colfax Avenue, Denver, CO 80206.

This work was supported by U.S. Public Health Services Grant 5R01-HD10032; Grant RR-69 from the General Clinical Research Centers Program of the Division of Research Resources, National Institutes of Health; The Genetic Foundation; and The Children's Hospital of Winnipeg Research Foundation.

Presented in part at the Western Society for Pediatric Research, 1984.

Following the submission of this manuscript, one pubertal aneuploid subject has been found to have a low percent mosaicism with karyotype $46, \mathrm{XY} / 46, \mathrm{XX}$ / $47, \mathrm{XXY}(6: 13: 175)$ in blood and fibroblasts. ondary sexual changes, basal serum hormone concentrations and acute responses to stimulation with gonadotropinreleasing hormone and human chorionic gonadotropin were normal. The timing of the onset of clinical puberty was normal. Early pubertal boys showed initial testicular growth and normal serum testosterone levels, while serum follicle-stimulating hormone and estradiol concentrations were significantly elevated. By midpuberty, the Klinefelter subjects were uniformly hypergonadotropic and their testicular growth had ceased. Serum testosterone concentrations after age 15 remained in the low-normal adult range. Serum estradiol levels remained high, irrespective of the presence or absence of gynecomastia. Exaggerated responses to gonadotropin-releasing hormone are seen in pubertal subjects with elevated basal gonadotropin values. (Pediatr Res 19: 82-86, 1985) 


$\quad$ Abbreviations
FSH, follicle-stimulating hormone
LH, luteinizing hormone
T, testosterone
E2, estradiol
GnRH, gonadotropin-releasing hormone
hCG, human chorionic gonadotropin

Klinefelter syndrome was first described in adult phenotypic males with gynecomastia, azoospermia, and hypergonadotropic hypogonadism, and was subsequently found to be associated with the presence of an extra X chromosome. Because the condition is rarely diagnosed until adult life, little is known about the natural history of the hypogonadism in young males with the 47,XXY karyotype.

In the past two decades, studies involving cytogenetic analysis of unselected neonates have provided an opportunity for the prospective study of boys with this karyotype. The growth, psychological development, and adolescent status of our subjects have been reported (14). The present report describes a study of pituitary-gonadal endocrine function in patients with $47, \mathrm{XXY}$ before and during puberty.

\section{MATERIALS AND METHODS}

Forty subjects with a 47,XXY karyotype were available for study. In each, cultured leukocyte chromosome analysis had failed to demonstrate mosaicism. Twenty-seven subjects (age 1$16 \mathrm{yr}$ ) were identified during neonatal screening programs in Denver, Winnipeg and Toronto (courtesy of Dr. John Bailey, Hospital for Sick Children), and thus represent an unselected group (12). The remaining 13 boys (age $7-19$ yr) were referred to these centers because of behavioral problems, gynecomastia, small testes, or micropenis, and were subsequently found to have a 47,XXY karyotype. No patient had received androgen supplementation for at least 4 months prior to being studied. A second group of 22 chromatin negative male siblings of the aneuploid subjects in the Denver Family Development Study was available as a control group for comparison with our previously published age-specific normal hormone values $(16,17)$.

Each subject had venous blood drawn at the initial assessment and at up to six subsequent visits, for determination of serum concentrations of FSH, LH, T, and E2. In $1547, \mathrm{XXY}$ individuals, ages 6-14 yr, more detailed testing of pituitary-gonadal function was carried out with sequential GnRH and hCG stimulation tests. An intravenous bolus of $200 \mu \mathrm{g}$ GnRH (gonadorelin, Factrel, Ayerst) was administered, and samples obtained at $-30,0,15,30,45,60,120$, and $180 \mathrm{~min}$ for assay of serum FSH and LH. Each subject also received 2000 units hCG (Pregnyl, Organon) intramuscularly on 3 consecutive days, followed by determination of serum T and E2 $24 \mathrm{~h}$ after the last injection (20). All samples were assayed in the same laboratory using previously described radioimmunoassays for FSH (4), LH (5), T (19), and E2 (19). The interassay coefficient of variance for each assay was less than $\pm 12 \%$ over the period of the study. The significance of differences between groups was evaluated by the nonparametric Mann-Whitney test because the data were not normally distributed. Informed consent was obtained from the parents.

\section{RESULTS}

The development of the 27 boys identified by newborn cytogenetic survey has been reported (14). All pubertal subjects have developed satisfactory secondary sexual characteristics. None showed any genital ambiguity. Prior to the first appearance of pubic hair, which usually occurred between ages 11-14 yr, most were growing at or above the 50th percentile for height and had a normal penile size. One boy, who was referred because of apparent micropenis $(2.6 \mathrm{~cm}$ at age $11 \mathrm{yr})$, later entered puberty spontaneously and showed normal penile growth. At age 10, the median testicular volume, using the Prader orchidometer, was 1 $\mathrm{ml}$ (range $0.5-2 \mathrm{ml}$ ). With the appearance of pubic hair (Tanner stage $\mathrm{PH}_{2}$ ) median testicular volume increased to $4 \mathrm{ml}$ (range 2$10 \mathrm{ml}$ ). Six boys were followed with annual examinations through puberty. Of these, five showed an initial increase and then a subsequent decrease in testicular size, whereas in the sixth, testicular volume remained at $2.5-3 \mathrm{ml}$. Therefore, at stage $\mathrm{PH}_{4-5}$ median testicular volume was only $3 \mathrm{ml}$ (range $2-7 \mathrm{ml}$ ). Of the seven patients referred after the age of $10 \mathrm{yr}$, gynecomastia was present initially or developed subsequently in five. One of six unselected pubertal boys (age $13 \mathrm{yr}$ ) has slight rounding of the aureola with no palpable glandular tissue.

The basal serum concentrations of FSH and LH in 47, XXY subjects are shown in Figure 1 . It can be seen that virtually all FSH and most $\mathrm{LH}$ values were normal before age 12 , but by age 14 the values for both were uniformly elevated. Figure 2 shows that the magnitude and timing of the initial adolescent rise in serum $\mathrm{T}$ were relatively normal. However, $\mathrm{T}$ levels plateaued after age 14 , and individual values subsequently failed to rise above the middle of the normal range. Serum FSH, LH, and T values for the control siblings fell within the normal range. Six of the 47,XXY boys showed slight elevations of E2 (up to $2 \mathrm{ng}$ / dl) before the clinical onset of puberty and before any rise in $\mathrm{T}$. A similar unexplained slight elevation was observed in one of the siblings, although E2 concentrations at this age (8-10 yr) were not significantly different between the two groups.

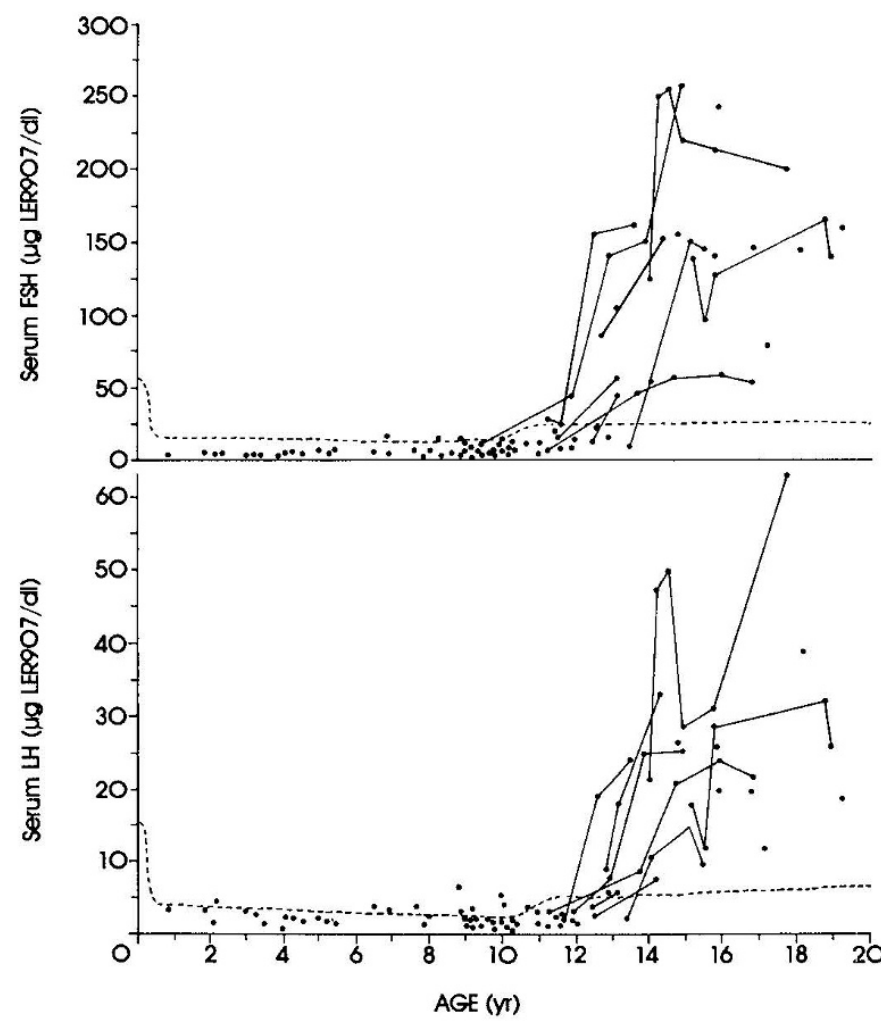

Fig. 1. Basal serum FSH and LH concentrations in boys with $47, \mathrm{XXY}$ before and during puberty. The dotted lines show the upper limit of the normal range in males (16). Successive values from the same subject are connected from the time they exceed the normal range. The FSH and LH, which are expressed in $\mu$ g LER907/dl, may be converted to IU/liter by multiplying the FSH value by 0.5 and the LH value by 4.5 . 
Table 1 compares median serum hormone levels in the $47, \mathrm{XXY}$ boys and the control siblings between ages 8 and $14 \mathrm{yr}$. At age $8-10$ yr there were no significant differences. At 11-12 $\mathrm{yr}, \mathrm{T}$ and E2 levels were higher in the 47, XXY boys, a possible indication that they had entered puberty slightly earlier than the control siblings. By age 13-14 yr their sex steroid concentrations were within the normal range, but the $47, X X Y$ subjects were clearly hypergonadotropic.

Because testicular size is not a valid index of pubertal development in Klinefelter syndrome, the subjects were assigned pubertal stages solely on the basis of pubic hair development. Table 2 summarizes the relationship of serum hormone concentrations to these pubertal stages. Increased serum concentrations of FSH and E2 were apparent by stage $\mathrm{PH}_{2}$. By midpuberty (stage $\mathrm{PH}_{3-5}$ ), the 47 , XXY boys were significantly hypergonadotropic, even though at this stage their T and E2 concentrations were not abnormal. Serum T and E2 levels in six boys at the time of diagnosis of gynecomastia were not significantly different from those in age-matched 47, XXY subjects without gynecomastia.

Stimulation tests with GnRH and hCG were carried out in late childhood and early puberty in an effort to uncover more

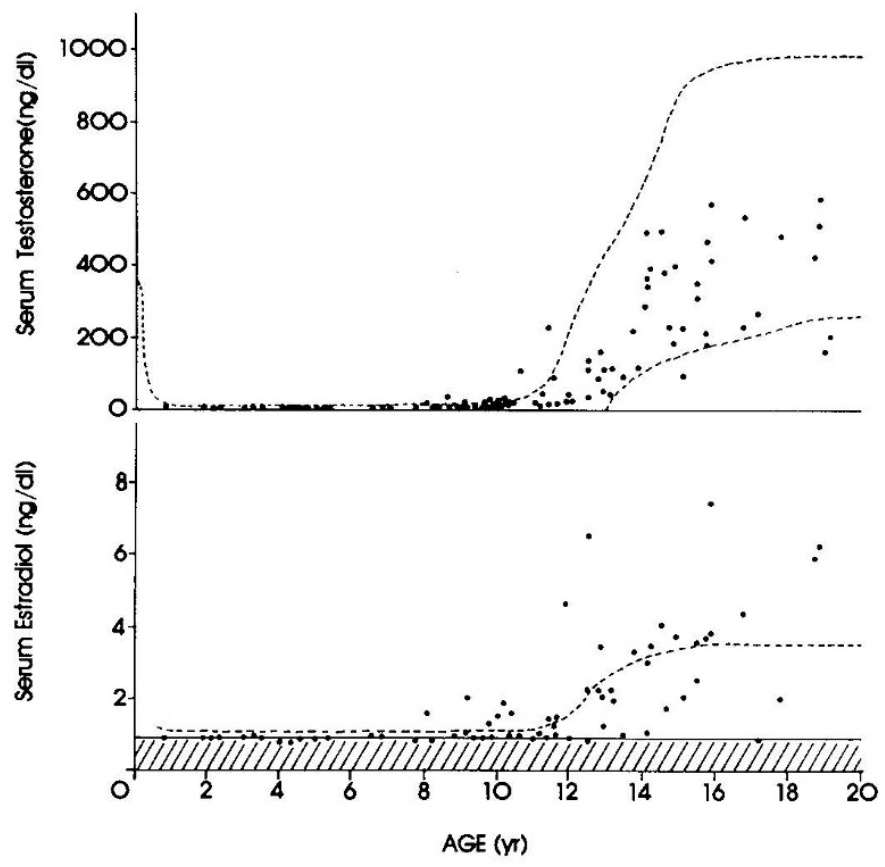

Fig. 2. Basal serum concentrations of $\mathrm{T}$ and $\mathrm{E} 2$ in boys with $47, \mathrm{XXY}$ before and during puberty. The dotted lines show the normal range for $\mathrm{T}$ and the upper normal limit for E2 (16). The shaded area shows the lower limit of sensitivity of the E2 radioimmunoassay. subtle abnormalities of pituitary-gonadal function. In response to 3 days of hCG stimulation (Fig. 3), all $1447, \mathrm{XXY}$ patients increased their serum $T$ level. In all but two, the peak $T$ value was at least as high as in normal boys at the same level of development (20), even though several patients already had elevated basal FSH and/or LH concentrations. The median posthCG peak serum E2 concentration was $1.8 \mathrm{ng} / \mathrm{dl}$ (range 1.0-3.4 $\mathrm{ng} / \mathrm{dl}$ ) in the prepubertal subjects and $2.7 \mathrm{ng} / \mathrm{dl}$ (range 1.0-6.9 $\mathrm{ng} / \mathrm{dl}$ ) in the early pubertal subjects, both of which are within the normal range (20). Similarly, hCG administration did not induce any significant abnormality in the E2/T ratio at this stage of puberty.

The peak FSH and $\mathrm{LH}$ responses to a single intravenous dose of GnRH are shown in Figure 4. Exaggerated responses were observed in 47,XXY boys who already had elevated basal serum gonadotropin values. However, acute GnRH stimulation did not evoke abnormal responses in subjects with normal basal FSH and LH levels.

\section{DISCUSSION}

Klinefelter syndrome is the most common form of male hypogonadism, but the definitive clinical picture of micro-orchidism, gynecomastia, and eunuchoidism does not appear until after midpuberty and may never be fully expressed. Children with the 47,XXY karyotype demonstrate relatively few clinical findings, although there may be some who show reduced testicular size or penile length. Their testes contain a reduced number of spermatogonia, but tubular fibrosis and hyalinization of seminiferous tubules are not observed until after the onset of puberty (6). The testes of adult patients reveal extensive fibrosis and hyalinization, while Leydig cell volume may be preserved (1). Clinical findings in the adult Klinefelter patient include absent or markedly reduced spermatogenesis, and hypergonadotropic hypogonadism with low-normal or frankly reduced levels of serum $\mathrm{T}$ and high-normal or elevated levels of serum E2 (7). Even in elderly patients, as testicular function declines further, this increased E2/T ratio is maintained (8).

The present study confirms that during childhood, and even into early puberty, pituitary-gonadal function is relatively normal in $47, X X Y$ subjects (15). In contrast to the elevated serum FSH values characteristic of completely agonadal individuals (18), all of our subjects had normal FSH levels before puberty. The few occurrences in late childhood of slightly increased serum LH levels for age, even though they were not accompanied by testicular enlargement or increased $\mathrm{T}$ values, may have been a sign of impending puberty. A slight increase in E2 was observed in six 47,XXY subjects before puberty, but the group's values were not significantly different from normal, and this finding does not appear to be characteristic of prepubertal patients with the karyotype.

The onset of puberty was determined as the first appearance of pubic hair because of the difficulty using testicular growth in

Table 1. Age-related serum gonadotropin and gonadal steroid concentrations in boys with a 47,XXY karyotype compared to control

\begin{tabular}{|c|c|c|c|c|c|c|}
\hline $\begin{array}{l}\text { Age } \\
\text { (yr) }\end{array}$ & Subjects & $n$ & $\begin{array}{c}\text { FSH } \\
(\mu \mathrm{g} / \mathrm{dl})\end{array}$ & $\begin{array}{c}\mathrm{LH} \\
(\mu \mathrm{g} / \mathrm{dl}) \\
\end{array}$ & $\begin{array}{c}\mathrm{T} \\
(\mathrm{ng} / \mathrm{dl})\end{array}$ & $\begin{array}{c}\mathrm{E} 2 \\
(\mathrm{ng} / \mathrm{dl})\end{array}$ \\
\hline \multirow[t]{2}{*}{$8-10$} & $47, \mathrm{XXY}$ & 17 & $8.1(3.8-15.0)$ & $2.6(1.3-6.7)$ & $14(<10-110)$ & $1.4(<1.0-4.6)$ \\
\hline & Controls & 5 & $7.0(4.1-11.0)$ & $2.5(1.5-3.6)$ & $10(<10-14)$ & $2.0(<1.0-2.0)$ \\
\hline \multirow[t]{2}{*}{$11-12$} & $47, \mathrm{XXY}$ & 10 & $15.8(6.3-85.0)$ & $2.5(1.9-8.7)$ & $50(14-227)^{*}$ & $1.4(<1.0-6.5)^{*}$ \\
\hline & Controls & 13 & $10.0(7.5-30.0)$ & $2.5(2.1-5.5)$ & $14(<10-145)$ & $1.0(<1.0-2.2)$ \\
\hline \multirow[t]{2}{*}{$13-14$} & $47, \mathrm{XXY}$ & 9 & $125.0(41.0-150)^{* *}$ & $17.6(5.8-33.0)^{* * *}$ & $216(92-498)$ & $2.1(<1.0-3.3)$ \\
\hline & Controls & 6 & $13.0(6.1-35.0)$ & $3.6(2.1-6.4)$ & $45(15-304)$ & $2.0(1.1-3.2)$ \\
\hline
\end{tabular}

Values are median with the range in parentheses. To reduce sampling frequency bias, each subject contributed no more than one specimen to each age interval. Differences between 47, XXY subjects and control siblings were calculated with a two-tailed Mann-Whitney test and are significant where indicated with ${ }^{*} p<0.05,{ }^{* *} p=0.001$, and ${ }^{* * *} p=0.002$. 
Table 2. Pubertal stage-related serum gonadotropin and gonadal steroid concentrations in boys with a 47,XXY karyotype compared to control siblings

\begin{tabular}{ccccccc}
\hline $\begin{array}{c}\text { Pubertal } \\
\text { stage }\end{array}$ & Subjects & $n$ & $\begin{array}{c}\text { FSH } \\
(\mu \mathrm{g} / \mathrm{dl})\end{array}$ & $\begin{array}{c}\text { LH } \\
(\mu \mathrm{g} / \mathrm{dl})\end{array}$ & $\begin{array}{c}\mathrm{T} \\
(\mathrm{ng} / \mathrm{dl})\end{array}$ & $\begin{array}{c}\mathrm{E} 2 \\
(\mathrm{ng} / \mathrm{dl})\end{array}$ \\
\hline $\mathrm{PH}_{1}$ & $47, \mathrm{XXY}$ & 40 & $8.0(3.6-23.0)$ & $2.5(1.3-6.7)$ & $14(<10-135)$ & $1.0(<1.0-6.5)$ \\
& Controls & 14 & $9.2(2.7-30.0)$ & $2.5(1.5-5.1)$ & $11(<10-145)$ & $1.0(<1.0-2.0)$ \\
& & & & & & \\
& & & & & & \\
$\mathrm{PH}_{2}$ & $47, \mathrm{XXY}$ & 6 & $42.5(15.0-150)^{*}$ & $5.4(1.1-19.0)$ & $69(<10-115)$ & $2.2(<1.0-4.6)^{* *}$ \\
& Controls & 9 & $11.0(6.1-16.0)$ & $2.5(2.1-4.8)$ & $15(<10-110)$ & $1.0(<1.0-2.2)$ \\
$\mathrm{PH}_{3-5}$ & $47, \mathrm{XXY}$ & 18 & $150(44.5-264)^{* * *}$ & $24.0(7.0-63.0)^{* * *}$ & $367(92-566)$ & $3.2(<1.0-7.4)$ \\
& Controls & 8 & $22.5(10.0-35.0)$ & $5.7(2.5-8.4)$ & $316(31-462)$ & $3.0(1.9-5.6)$ \\
\hline
\end{tabular}

Values are median with the range in parentheses. To reduce sampling frequency bias, no more than one specimen was included from each subject per year. Pubertal stage was assigned according to pubic hair development. Differences between $47, \mathrm{XXY}$ subjects and control siblings were calculated with a two-tailed Mann-Whitney test and are significant where indicated with ${ }^{*} p=0.003,{ }^{* *} p<0.05$, and ${ }^{* * *} p<0.001$.

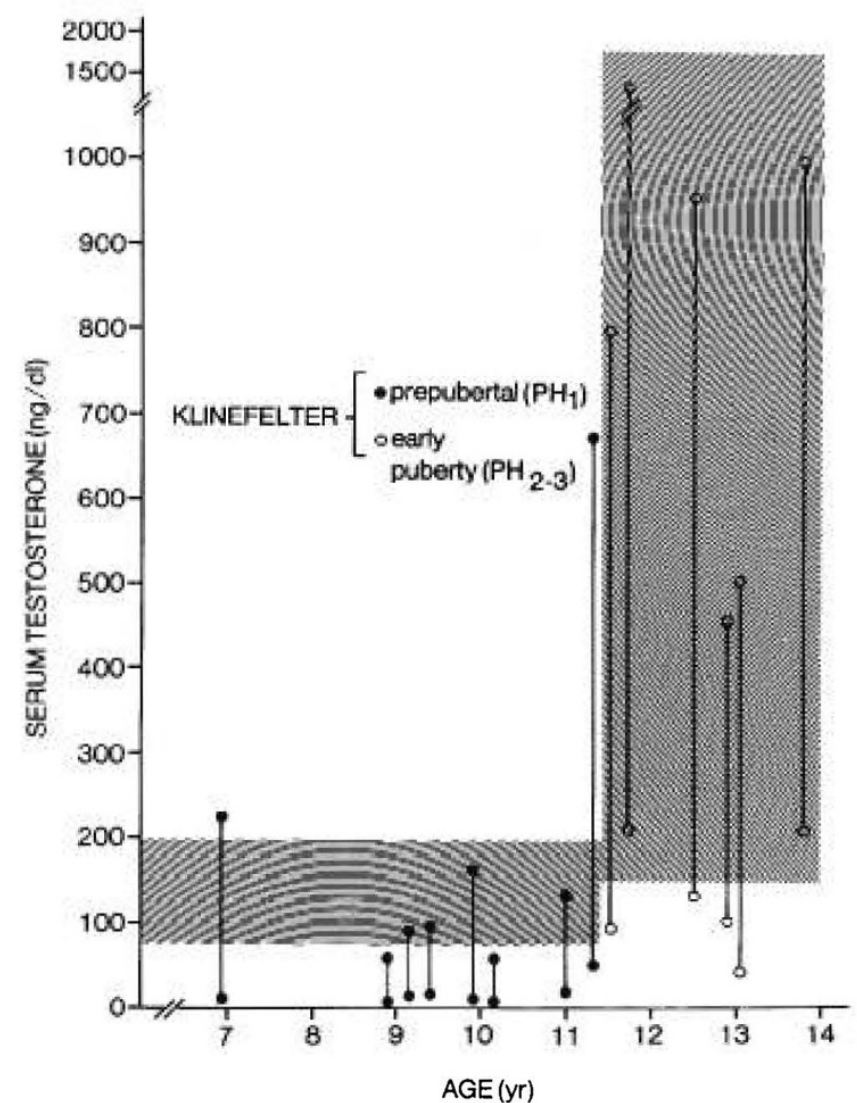

Fig. 3. The serum $\mathrm{T}$ response to 3 daily $2000 \mathrm{U}$ doses of $\mathrm{hCG}$ in boys with a $47, \mathrm{XXY}$ karyotype before puberty $(\bullet)$ and after the appearance of pubic hair $(O)$. The basal and peak poststimulation values for each subject are connected. The shaded area indicates the normal range for peak values observed in healthy prepubertal and early pubertal boys (20).

Klinefelter patients. Its occurrence was at least as early as in the control siblings and was accompanied by a normal initial rise in serum $T$ level. The observed testicular volumes for the 47, XXY patients at puberty stage $\mathrm{PH}_{2}$ were only slightly smaller than those (mean $5 \mathrm{ml}$, range $3-10 \mathrm{ml}$ ) observed in the normal population. However, after an initial increase in size, continued testicular growth did not occur, and no patient even approached the normal adult mean volume of $15 \mathrm{ml}$ (range $12-25 \mathrm{ml}$ ).

Even though their $T$ concentrations during early puberty were similar or greater than the controls, and within the normal range for age or pubertal stage (16), many Klinefelter subjects showed abnormal serum FSH values soon after clinical puberty was apparent, and by midpuberty they were clearly hypergonado-
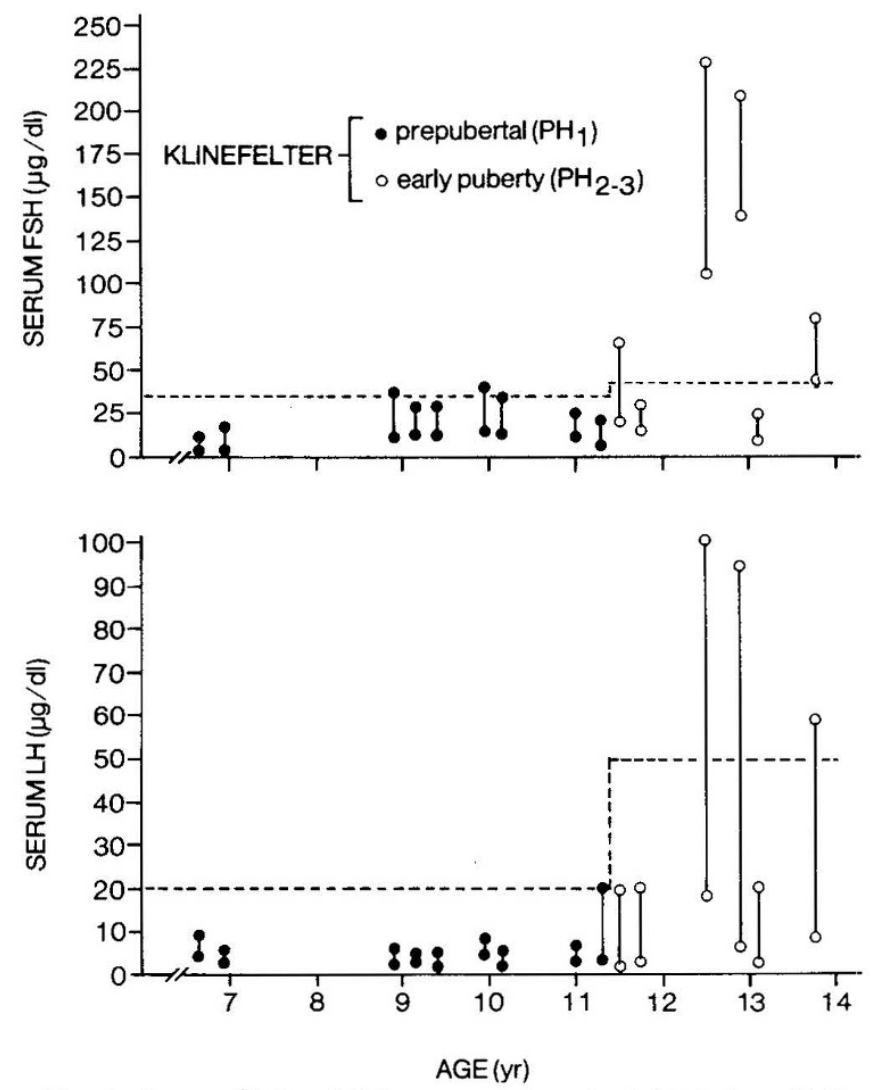

Fig. 4. Serum FSH and LH responses to a single IV bolus of $200 \mu \mathrm{g}$ GnRH in $47, X X Y$ boys before puberty ( $)$ and after the appearance of pubic hair $(\mathrm{O})$. The basal and peak poststimulation gonadotropin values for each subject are connected. The dotted line indicates the upper limit of peak post-GnRH values observed in healthy prepubertal and early pubertal boys.

tropic (present study and Ref. 11). High E2 concentrations were found throughout puberty. Particularly in early puberty, many patients showed a high E2/T ratio, which presumably accounts for the frequent occurrence of gynecomastia $(3,9)$. High E2 levels might also be expected to induce relatively high levels of sex hormone-binding globulin, thus further reducing serum free $\mathrm{T}$ (2). In Klinefelter syndrome, high E2 levels appear to reflect increased testicular estrogen secretion rather than enhanced peripheral aromatization (13), a phenomenon which likely results from excessive FSH stimulation (10). It is of interest that the administration of hCG in our study, which is an LH-like stimulus, does not further increase the E2/T ratio in these hypergonadotropic individuals (7). 
The basic endocrine defect in Klinefelter syndrome appears to be gonadal. The relative roles of the testicular structure and function observed at puberty and elevated gonadotropin secretion is not presently understood. We found that during childhood, serum gonadotropin levels are normal even following GnRH stimulation. By midpuberty, Klinefelter subjects are hypergonadotropic, even though their basal $\mathrm{T}$ levels are not markedly reduced and $T$ secretion can be increased further either by the administration of hCG or infusion of sufficient GnRH to raise endogenous LH even further. It would appear that high circulating gonadotropin levels may exacerbate the primary testicular lesion and cause the progressive hyalinization and fibrosis. Eventually, testicular damage or a local effect of intratesticular estrogen leads to diminished $T$ reserve. It remains to be seen to what extent early aggressive $T$ therapy might influence the course of this adolescent endocrine dysfunction.

Acknowledgments. The authors thank Dr. John F. LaBrecque for statistical consultation and Jean Clyne for help in preparation of the manuscript.

\section{REFERENCES}

1. Ahmad KN, Dykes JRW, Ferguson-Smith MA, Lennox B, Mack WS 1971 Leydig cell volume in chromatin-positive Klinefelter's syndrome. $J$ Clin Endocrinol Metab 33:517.

2. Blank B, Attanasio A, Rager K, Gupta D 1978 Determination of serum sex hormone binding globulin (SHBG) in preadolescent and adolescent boys. $J$ Steroid Biochem 9:121

3. Carlson HE 1980 Gynecomastia. N Engl J Med 303:795

4. Faiman C, Ryan RJ 1967 Radioimmunoassay for human follicle stimulating hormone. J Clin Endocrinol Metab 27:444

5. Faiman C, Ryan RJ 1967 Radioimmunoassay for human luteinizing hormone. Proc Soc Exp Biol Med 125:1130

6. Ferguson-Smith MA 1959 The prepubertal testicular lesion in chromatin- positive Klinefelter's syndrome (primary micro-orchidism) as seen in mentally handicapped children. Lancet $1: 219$

7. Forti G, Giusti G, Borghi A, Pazzagli M, Fiorelli G, Cabresi E, Mannelli M, Bassi F, Giannotti P, Fusi S, Serio M 1978 Klinefelter's syndrome: a study of its hormonal plasma pattern. J Endocrinol Invest 2:149

8. Gabrilove JL, Freiberg EK, Thornton JC, Nicolis GL 1979 Effect of age on testicular function in patients with Klinefelter's syndrome. Clin Endocrinol $11: 343$

9. Lee PA 1975 The relationship of concentrations of serum hormones to pubertal gynecomastia. J Pediatr 86:212

10. Pomerantz DK 1983 Interactions of follicle-stimulating hormone and luteinizing hormone in controlling estradiol synthesis by the testis of the infant rat. Biol Reprod 28:890

11. Ratcliffe SG, Bancroft J, Axworthy D, McLaren W 1982 Klinefelter's syndrome in adolescence. Arch Dis Child 57:6

12. Robinson A, Puck M, Pennington B, Borelli J, Hudson M 1979 Abnormalities of the sex chromosomes: a prospective study on randomly identified newborns. In: Robinson A, Lubs HA, Bergsma D (eds) Sex Chromosome Aneuploidy: Prospective Studies on Children. Birth Defects 15:203

13. Sharma DC, Gabrilove JL 1971 Biosynthesis of testosterone and oestrogens in vitro by the testicular tissue from patients with Klinefelter's syndrome. Acta Endocrinol 66:737

14. Robinson A, Bender B, Puck M, Salbenblatt J, Webber L 1982. In: Stewart DA (ed) Children with Sex Chromosome Aneuploidy: Follow-up Studies, Birth Defects 18:7

15. Topper E, Dickerman Z, Prager-Lewin R, Kaufman H, Maimon Z, Laron Z 1982 Puberty in 24 patients with Klinefelter syndrome. Eur J Pediatr 139:8

16. Winter JSD 1978 Prepubertal and pubertal endocrinology. In: Faulkner F, Tanner JM (eds) Human Growth, Vol. 2. Postnatal Growth. Plenum Press, New York, pp 183-213

17. Winter JSD, Faiman C 1972 Pituitary-gonadal relations in male children and adolescents. Pediatr Res 6:126

18. Winter JSD, Faiman C 1972 Serum gonadotropin concentrations in agonadal children and adults. J Clin Endocrinol Metab 35:561

19. Winter JSD, Hughes IA, Reyes FI, Faiman C 1976 Pituitary-gonadal relations in infancy: 2. Patterns of serum gonadal steroid concentrations in man from birth to two years of age. J Clin Endocrinol Metab 42:679

20. Winter JSD, Taraska S, Faiman C 1972 The hormonal response to hCG stimulation in male children and adolescents. $\mathrm{J}$ Clin Endocrinol Metab $34: 348$

\title{
Studies on Requirements for Amino Acids in Infants with Disorders of Amino Acid Metabolism. I. Effect of Alanine
}

\author{
DREW G. KELTS, DENISE NEY, ${ }^{1}$ CAROLYN BAY, JEAN-MARIE SAUDUBRAY, AND \\ WILLIAM L. NYHAN \\ Department of Pediatrics [D.G.K., C.B., J-M.S., W.L.N.] and the General Clinical Research Center [D.N.], \\ University of California San Diego Medical Center, San Diego, California 92103
}

\begin{abstract}
Two infants with disorders of propionate metabolism were studied at 7 months of age to determine optimum levels of intake of protein and calories to meet the requirements for essential amino acid for growth in
\end{abstract}

Received December 1, 1983; accepted August 1, 1984.

Reprint request to Dr. William L. Nyhan, Department of Pediatrics, M-009, UCSD School of Medicine, La Jolla, CA 92093

Aided in part by the UCSD General Clinical Research Center National Institutes of Health Division of Research Resources, Grant RR-00827 and Grant 04608 from the National Institute of Child Health and Human Development, National Institutes of Health, Bethesda, MD.

This work performed whib J-M.S. was on sabbatical from Hospital NeckerEnfants Malades, Clinique Genetique Salle Gillette 149 Rue de Sevres, Paris, France 75730

' Present address; c/o Nutrition Department, UC Davis, Davis, CA 95616. infancy, and at the same time minimize the accumulation of toxic intermediates. An effect of alanine was found that permitted growth at otherwise limiting levels of protein intake. This was not simply an effect of nonessential nitrogen as neither glycine nor glutamic acid could substitute for alanine in this protein-sparing effect. This appears to represent further evidence of the relationship between alanine and the branched-chain amino acids and of the importance of the alanine-glucose cycle in human physiology. (Pediatr Res 19: 86-91, 1985)

Abbreviation

BA, baseline period 